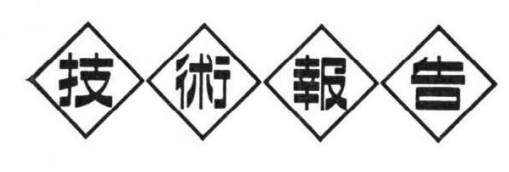

\title{
CFRP 製ターボチャージャーインペラーの開発
}

\section{1. はじめに}

1979 年にわが国で初めて当社製品にターボチャー ジャーが採用されて以来, ターボ車の普及と共に, 加 速レスポンス性の向上, すなわ出、いわゆるターボラ グ(アクセルペダルを踏んだときから加速開始までの 遅れの感覚）の低減への要求が増してきている.

ターボチャージャー（図 1) は, 排気ガスの高温・ 高压エネルギーを利用してタービンローター（ロータ 一）を駆動し，同軸上に配置したコンプレッサーイン ペラー（インペラー）により，吸入空気を圧縮して燃 焼室に送る構成となっている. ターボラグ低減の手法 の中では, ターボチャージャーの回転体であるロータ 一およびインペラーを軽量化し, 慣性モーメントを低 減させることが非常に効果的である.

ローターについては, 従来の耐熱合金（比重 8.2） と比較して非常に軽い構造用セラミックス材料（比重 3.2）が，1985 年に当社で採用されている.インペラ 一については現行のアルミ合金（比重 2.7）に代わり, マグネシウム合金（比重 $1.7 \sim 1.8$ ) や CFRP（比重 1.3〜1.5) の適用が検討されている1) が, 樹脂（CF RP) を採用しょうとした場合, 高温での強度や信頼 性の確保, 量産成形性の確立, トータルコストの低減 などが容易でなく、これまで量産車で実用化された例 はない.

筆者らは数年間にわたり樹脂製インペラーの開発に 取り組み, 上記の課題を解決することにより, 樹脂製 インペラーを量産車に搭載した（1994 年 9 月より口

\footnotetext{
*1 Tomaru Ogawa, Koichi Handa 日産自動車(株) 総合研究所 材料研究所 横須賀市夏島町 1 ( ( 237 )

*2 Tamaki Asakawa 同社 技術開発センター 厚木市岡津古久 560-2 (

*3 Katsuyuki Yamamoto 同社 第一試作部 技術課 同上
} 1995. 2.24 受理

\author{
小川 止*1 半田浩一*1 \\ 浅川玉樹*2 - 山本克之草
}

ーレルに搭載).ここでは, 特に射出成形による量産 成形用型の開発を中心に報告する.

\section{2. 材料}

インペラーにかかる負荷には, 10 万 $\mathrm{rpm}$ 以上で高 速回転するために生じる遠心力括よびスラスト荷重と, タービン側から回転軸を介して伝わる, および空気を 圧縮することにより発生する熱（コンプレッサー出口 温度で $115^{\circ} \mathrm{C}$ に達する)などがある．これらの負荷に 耐える樹脂材料として, 各種スーパーエンプラを炭素 繊維で強化した材料が候補にあがったが，単に既存材 料を適用しただけでは要求性能は得られなかった。

\section{1 炭素織維の表面処理}

炭素繊維強化のスーパーエンプラは成形温度が高い (約 $400^{\circ} \mathrm{C}$ ) ため, 纎維と樹脂を接着するサイジング剂 （カップリング剂）が成形中に熱分解して充分な引張 強さが得られないといら問題があった。そこで新規に, 熱安定性と接着性に優れたスーパーエンプラのサイジ ング剂を開発し，引張強さを $20 \sim 45 \mathrm{MPa}$ 改善するこ とができた。

図 2 に CFRP の引張試験による破断面を示す. （a）は市販のサイシシング剂使用時，（b）は本開発に よるサイジング剤使用時であり，(a) では繊維が抜 けて破断しているのに対し（b）では樹脂が繊維に 付着したまま破断しており，界面の接着強さが向上し

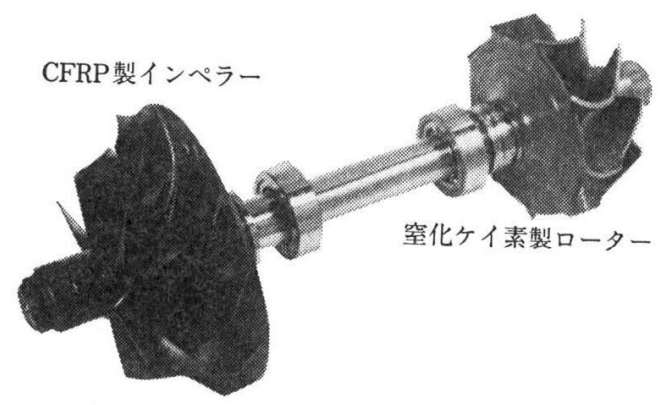

図 1 自動車用ターボチャージャー（回転部分） 


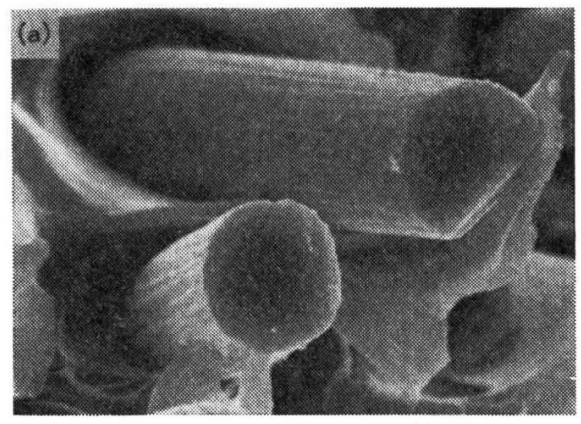

（a）市販のサイジンク剤使用時

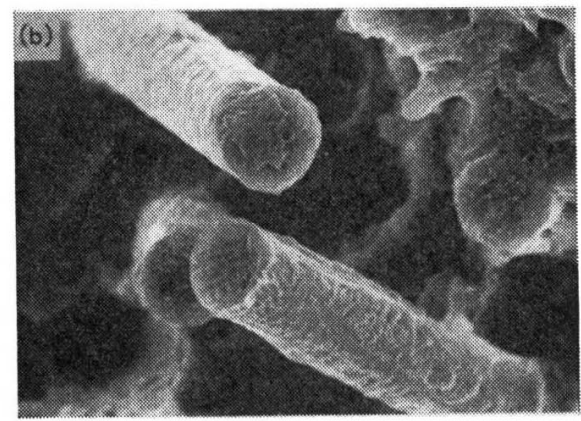

(b) 開発品サイジング剤使用時

図 2 引張試験による CFRP の破断面

ているのがわかる。

\section{2 マトリックス樹脂の改善}

インペラー用材料の性能を比較する指標として, 瞬 時破壊回転数を用いた. これはインペラーを回転軸に 装着・回転し, 徐々に回転数を増加していき, 破壊し たときの回転数である. $30 \%$ 炭素繊維強化スーパー エンプラを用いてィンペラーを成形し, 瞬時破壊回転 数を比較したものを図 3 に示す. 瞬時破壊回転数は材

表 1 インペラー用樹脂とアルミ合金の機械的性質

\begin{tabular}{|c|c|c|}
\hline 材 料 & 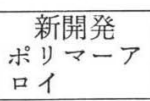 & $\begin{array}{l}\text { アルミ合金 } \\
\mathrm{AC} 4 \mathrm{D} \text { 相 } \\
\text { 当材 }\end{array}$ \\
\hline 比 & 1.38 & 2.7 \\
\hline 引張強さ $(\mathrm{MPa})$ & $290[180]$ & $320[265]$ \\
\hline 比強度 $(\mathrm{MPa})$ & $210[130]$ & $119[98]$ \\
\hline 引張弾性率 (GPa) & 25.3 & 72.5 \\
\hline 破断伸び (\%) & 1.6 & 3.8 \\
\hline $10^{7}$ 疲労限度 $(\mathrm{MPa})$ & $155\{140\}$ & $-\{123\}$ \\
\hline (比重換算値) (MPa) & $112\{101\}$ & $-\{46\}$ \\
\hline クリープ破断応力 $(\mathrm{MPa})$ & $-[127]$ & $-[132]$ \\
\hline (比重換算值) (MPa) & $-[92]$ & \ulcorner \\
\hline
\end{tabular}

[ ] ，\{ \}内はそれぞれ 100, $150^{\circ} \mathrm{C}$ におけるデータ（他は 室温)，(比重換算值）はそれぞれの值を比重で除した値. 1000時間で試験片が破断する応力をクリープ破断応力とし た.

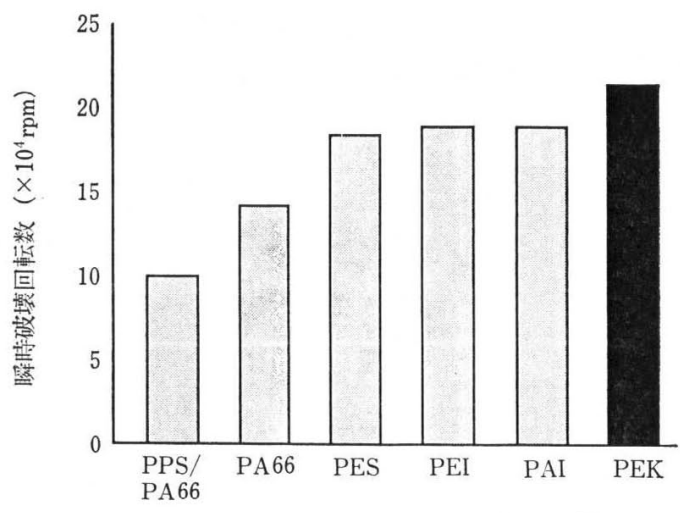

マトリックス樹脂 (30\%炭素織維強化)

図 3 CFRP 製インペラーの瞬時破壊回転数

料の強度と破壊じん性のバランスによって決まるが， 単一材料之しては PEK が最も優れていることがわか った.

$\mathrm{PEK}$ のガラス転移温度は $154^{\circ} \mathrm{C}$ であり, 将来のエ ンジンの高性能化を考慮すると充分とはいえない，そ こで, PEK を PI 系の樹脂とのアロイとすることで, 破壊じん性を損ならことなく，ガラス転移温度を 194 ${ }^{\circ} \mathrm{C}$ に改善することができた.

これらの改良によって, 従来インペラーに使用され ているアルミ合金と比較して比強度, 比重当たりの疲 労限度, クリープ寿命とも上回る樹脂材料が得られた。 本開発による樹脂材料とインペラー用アルミ合金の物 性の比較を表 1 に示す.

\section{3. 成形}

\section{1 インペラーの成形方法}

アルミ合金製インペラーは，切削品の原形の形状を ラバーモールド法により石膏型に転写し, そこへアル ミ溶湯を流し込んで成形される。この方法は, 工程が 複雑であるら充に人手も䖪かり, コスト高である、樹 脂製インペラーの場合, 前項に述ベた炭素緎維強化ス ーパーエンプラを用いているので，材料費はアルミ合 金より飛躍的に高い. したがって, 加工のコストを下 げるため, 成形方法は射出成形とする必要がある.

\section{2 回転体の射出成形型}

ローター扰よびインペラーはいずれも翼をもつ回転 体であるが，その形状は大きく異なる。ローターの翼 は回転軸と平行に近い形状（ラジアル型）で, 翼の㨝 れが少ないので，これを射出成形する場合，翼を形成 する分割型（入れ子）を径方向に同時に移動すること により，容易に金型の開閉ができる.これに対し，イ ンペラーの場合は翼の湾曲・倒れ 达みが大きい形状 (バックワードレイク型) のため, 径方向に分割しよ 


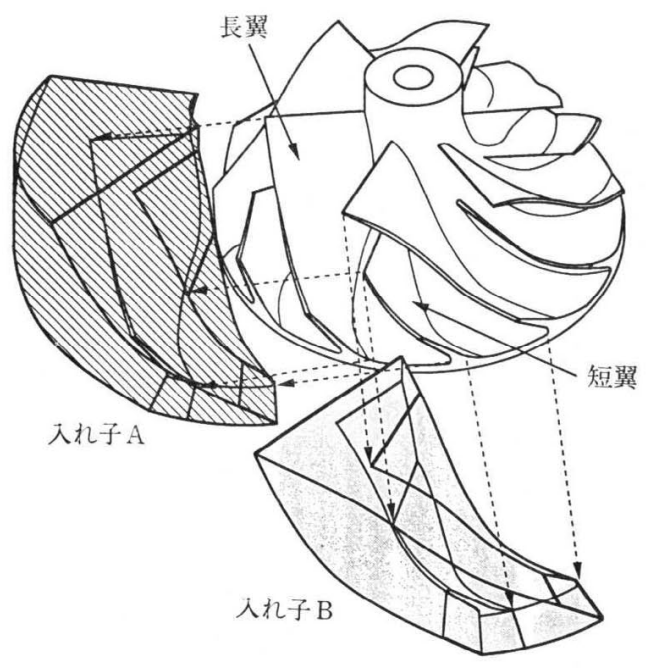

図 4 インペラー部品および入れ子形状

らとすると，成形品翼部と金型が干渉してしまい，型 開きできないので, ローターと同様の成形方法は採れ ない.

他の成形方法としては,

(1) 金型を上下 2 分割し，それぞれ入れ子型にして 型を構成する方法,

(2) まず翼部を成形し，それをインサートとして胴 体部を成形する方法,

などが考えられる. しかし，(1)は形状が限定され，イ ンペラーの形状に適用しにくいら光, 翼表面に, 流線 と直角にパーティングライン (PL) が残るので, 性能 面で悪影響を及ぽすといら問題がある。また，(2)は， 翼部をインサートとして型内に置くときの位置決め・ 保持の機構や翼と胴（軸部）の接合部の強度に問題が ある. したがって, 翼胴を一体で成形し，から流れを 乱す部分に PL が位置しないように, 三次元的に入れ 子を分割した構成とする必要があることがわかった。

この型構造は非常に複雑になるので, 三次元ソリッ ドモデラーを使ったシミュレーションにより検討した. その手順を以下に述べる。

\section{3 入れ子型抜き方法の決定}

代表的なインペラーの形状は, 図 4 に示すよらに長 翼と短翼が交互に配置されている，したがって，入れ 子形状は同図に示す A, B の 2 種類がある. 長・短翼 の翼面形状は共通であり,基本的に高さのみが異なる. 入れ子を分割・型開きする方法として，まず，分割し た入れ子を直線で引き抜くことが考兄られる，前述の よらに，インペラー回転軸と直交する平面上に抜き方 向を設定することは不可能なため，回転軸と捩れの関 係にある抜き方向を設定できないか検討した（図 5 ). その結果, 長翼が短翼にかぶさる形になっているため,

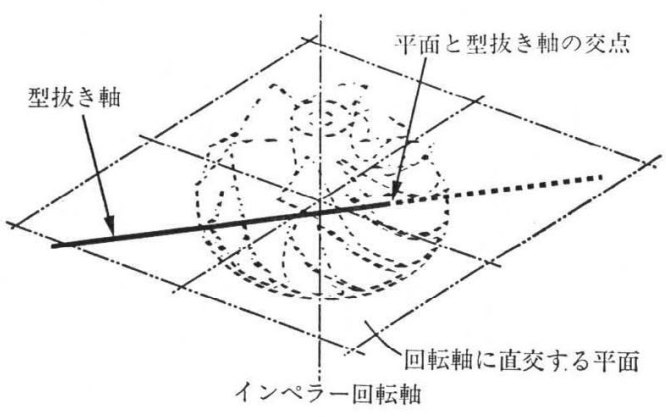

図 5 回転軸と㨝れの関係にある抜き方向

入れ子 $\mathrm{A} に は$ 直線で抜ける方向が存在するが，入れ子 Bはどの方向にも抜くことが不可能であり，より複雑 な方法でなければ抜けないことがわかった。

具体的には,

(1) 曲線（円弧など）に沿って抜く,

(2)直線上を回転させながら抜く，

などの方法が考学られるが，(1)の方法は型設計，製造 時の曲線の定義が難しいため, (2)の方法をモデラー上 で試み，干渉を起こさない抜さ方向，回転角の組み合 わせを見出した．乙かし，この方法で全ての入れ子を 同時に抜こらとすると, 型同士の干渉が起こるため, 実現できないことがわかった。

そこで，入れ子Aをまず直線で抜き，次に入れ子 B を回転しながら抜くという手順を検討し，干渉の起き ないような抜き方向・距離・角度を決定することがで きたささらに，入れ子のパーティング部の設計に当た っては，入れ子の移動に祭して干渉しないように，ま た，成形時の圧力，温度に充分耐え，かつ入れ子を組 み合わせてキャビティを形成することが容易に行える ように考慮した.

この一連の動作を実現するための 金型の 概略構造 ${ }^{22}$ を図 6 に示寸，入れ子 a のガイド部 bにらせん状の溝 cを設け，これに嵌合するピンdをべース e に設置し た構造により，a（およびb）の抜き動作（直線上の 移動)に伴い, a (およびb) が回転する。また，入 れ子の抜き動作は，リンク $\mathrm{f}$ をしてェジェクタロッ ド $\mathrm{g}$ と連動させることにより, 型開閉時の作動性を確 保した。

\section{4 樹脂化に伴う設計変更}

樹脂化したことにより，材料の弾性率や強度の絶対 值はアルミに比較して小さくなっているため, また射 出成形型で成形可能とするため, インペラーの形状を 以下のよらに変更した。なお, これらの形状変更に際 しては比較試験を行い, ターボチャージャーとしての 性能に影響がないことを確認した。 

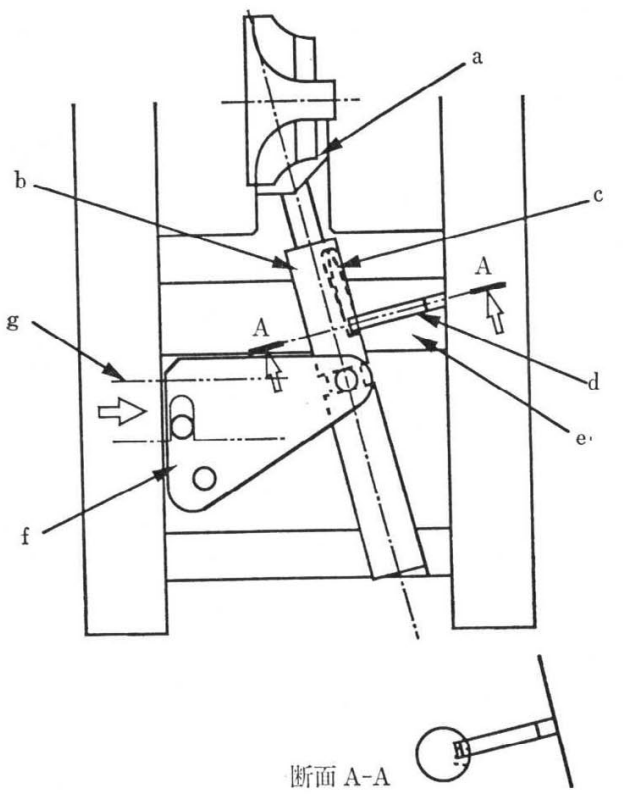

図 6 金型概略構造 2 )

\section{a. 背板 $\boldsymbol{R}$ 部の形状変更 (図 7 )}

インペラー各部にかかる応力は, 回転時の遠心力に よるものが支配的であるＦEM を用いた計算により， 回転時に背板の一般部之衫じの「座」をつなぐ $R$ 部に 応力集中が発生することが判明したため，この部分の 形状を変更（ $R$ を大きくする） し，発生する応力を低 減した.

\section{b . 翼根 $\boldsymbol{R}$ 部の形状変更（図 8)}

前項と高同様に, 回転時の応力集中を避けるため翼 の付け根部分（鋭角側）のRを大きくした。

c. 翼前端の形状変更 (図 9 )

金型のパーティング位置の関係上, 翼前端部の両側
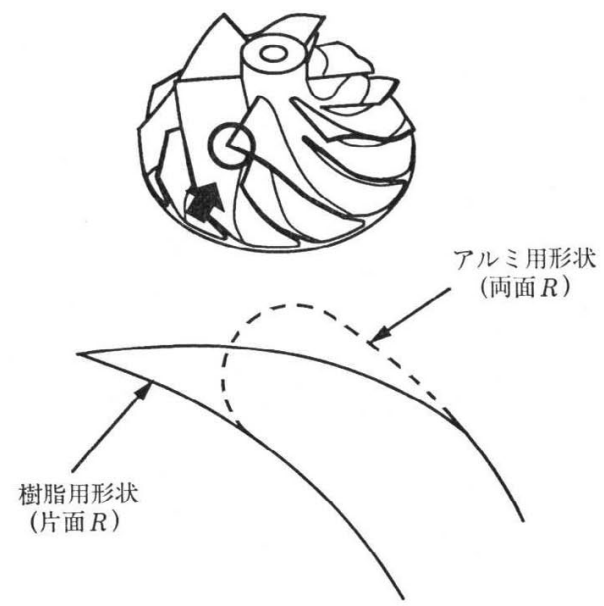

図 9 翼先端部の形状变更 (上部○印矢視図)

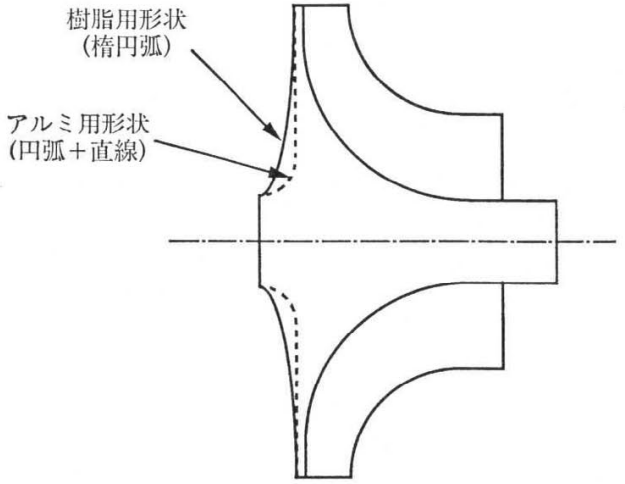

図 7 背板 $\boldsymbol{R}$ 部の形状变更 (インペラー断面図)

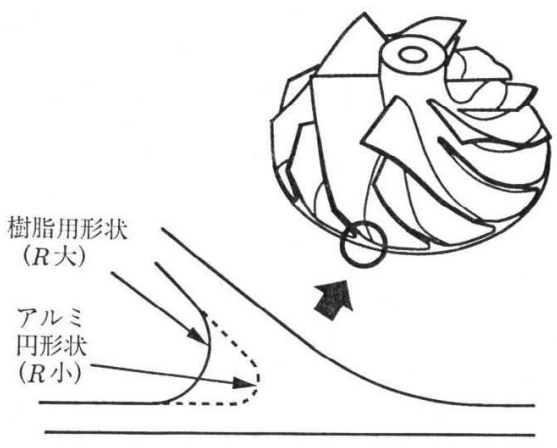

(背板側)

図 8 翼根 $\boldsymbol{R}$ 部の形状变更（上部 $\bigcirc$ 印矢視図）

にRを設けることが困難なため，Rを片側のみとし， 大きくした．これにより翼形状の入れ子への彫り込み が片面で済むため，金型の精度が向上できた。

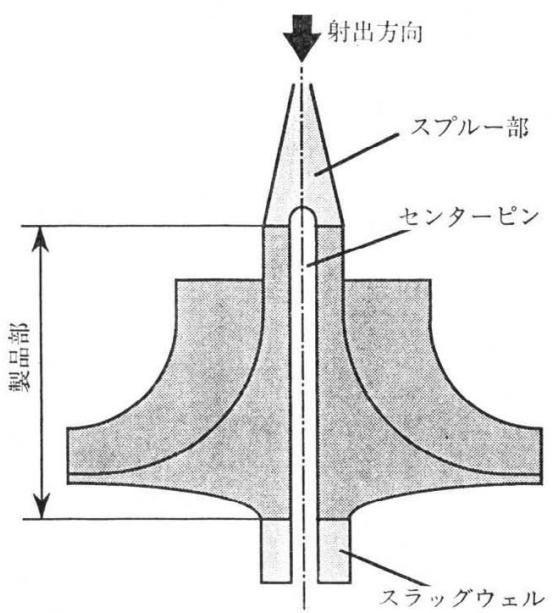

図 10 樹脂だまり（スラッグウェル，キャビティ形 状断面図) 


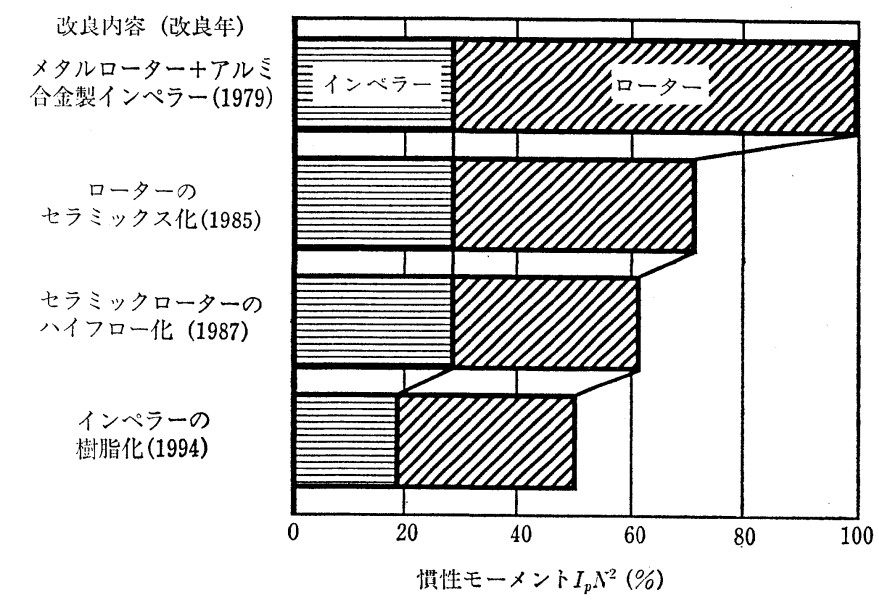

\section{4. 品質保 証}

樹脂製インペラーは成形温度が高く，また肉厚の大 きい部品のため, 内部欠陥が発生しやすい。このため, 成形条件の最適化と内部欠陥検查法の確立が重要であ る.

成形条件については, 実験計画法や品質工学の手法 を適用し，最適な成形条件を見出したままた，樹脂の 流れを制御するため, 図 10 に示すようにキャビティ 末端に樹脂だまり（スラッグウェル）を設け，最大応 力部付近に括ける繊維配向の最適化を図った.

内部欠陥の検査については，各種非破壞検査装置を 比較検討した結果, 欠陥検出能力や検査時間などの面 から超音波探傷映像装置が最適であることがわかった. この装置を用いることにより，数十 $\mu \mathrm{m}$ の大きさの内 部欠陥を検出できるようになり，極めて高い信頼性を 確保することができた。

さらに, 成形品からの切出試験片によるクリープ試 験や，成形品による台上括よび実車耐久試験に括いて 問題ないことを確認した.

\section{5. インペラー樹脂化の効果}

本開発による樹脂製インペラーを用いたターボチャ ージャーと, 従来材料を用いたターボチャージャーと の比較を以下に示す.

図 11 に, ターボチャージャーの改良による慣性モ 一メントの変化を示す. インペラーの材料をアルミ合 金から樹脂にすることにより,インペラー単体での重 量, 慣性モーメントはそれぞれ約 50\%，37\% 低減で きた. 図 12 に, 実際にインペラーを車両に装着した 場合の, インテークマニホールド内の圧力変化を示す.

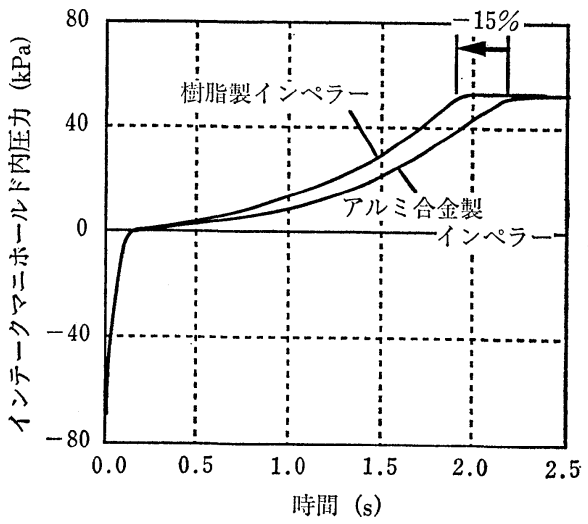

図 12 インテークマニホールド内の圧力変化 ( 2 速 $20 \mathrm{~km} / \mathrm{h}$ から全開加速した場合)

インターセプトタイム（アクセルを踏んだときから設 定過給圧までの到達時間）が約 15\% 短縮され, ター ボラグが大幅に改善されているのがわかる.

\section{6. おわりに}

以上述べたように，材料・成形・品質保証のそれぞ れの問題を克服し，市販車に搭載できる樹脂製インペ ラーを開発した.

本開発は三井東圧化学，エンプラスのご協力により 完遂できました。ご尽力いただきました両社に感謝の 意を表します。

\section{参考 文 献}

1）川澤紀生 : 自動車の最新技術事典（井口雅一，山 川新二, 池上 詢, 阿部正人，岩元貞雄, 花岡正 紀, 秦 好孝編), 128 129 (1993), 浅倉書店

2) 吉永広芳 : 型技術, 6 ( 8 ), 116 (1991) 